\title{
TOXIC EFFECTS OF MERCURY ON THE HARD CLAM, MERETRIX LUSORIA, IN VARIOUS SALINITIES
}

\author{
Tzong-Shean Chin and Hon-Cheng Chen* \\ Department of Zoology, National Taiwan University, Taipei, Taiwan 106, R.O.C. (Fax 3638554)
}

(Received 4 January 1993; accepted for publication 5 February 1993)

\begin{abstract}
The 96-hr $\mathrm{LC}_{50}$ values for juvenile hard clams, Meretrix lusoria, were 328, 392 and $194 \mu \mathrm{g} / \mathrm{l}$ $\mathrm{Hg}$ in 10,20 and $30 \mathrm{ppt}$ salinities at $25 \pm 1^{\circ} \mathrm{C}$, respectively; for adult hard clams 341 and $140 \mu \mathrm{g} / \mathrm{l} \mathrm{Hg}$ in 20 and $30 \mathrm{ppt}$ salinities, respectively.

2. Acclimatizing the adult clams to low salinity of $10 \mathrm{ppt}$ lessened the toxicity of mercury. However, juvenile animals appeared to be more sensitive to mercury poisoning after $96 \mathrm{hr}$ exposure in $10 \mathrm{ppt}$ salinity.

3. All embryos exposed to $40 \mu \mathrm{g} / \mathrm{l} \mathrm{Hg}$ and above died within $30 \mathrm{hr}$. In the control, $44 \%$ of hatched embryos had developed into D-stage larvae, while those exposed to $20 \mu \mathrm{g} / \mathrm{l} \mathrm{Hg}$ were still in the trochophore stage. Most of the retarded larvae developed into abnormal forms within $30 \mathrm{hr}$ at $28^{\circ} \mathrm{C}$ in $15 \mathrm{ppt}$ salinity.

4. In order to maintain water quality and protect natural resources, the recommended safe level of mercury is $0.046(0.039-0.053) \mu \mathrm{g} / \mathrm{l} \mathrm{Hg}$, based on the estimated $30-\mathrm{hr} \mathrm{EC}_{50}$ for the clam embryos, with an application factor of 0.01 .
\end{abstract}

\section{INTRODUCTION}

Heavy metals have long been recognized as serious pollutants in the aquatic ecosystem, showing deleterious or even toxic effects on associated organisms. For example, green oyster, caused by a high accumulation of copper, was observed in Taiwan at the Charting coastal area (Hung et al., 1989). Minamata Disease, caused by the consumption of fish and shellish containing a high concentration of mercury, has also been well documented (Irukayama et al., 1962; Yoshida et al., 1967). The hard clam, Meretrix lusoria, is one of the most important edible bivalve molluscs in Taiwan. Mass mortality of cultivated clams in coastal waters, which has occurred during the months of April and May each year since 1969, has mainly been attributed to the toxic effect of polluted water discharged from the industrial plants in the upstream areas of rivers. (Tseng, 1976; Chen, 1984).

Mercury, one of the group II B metals, has been recognized as being a highly toxic element to aquatic fauna (Chen, 1980; Hsieh and Chen, 1980; Chen and Chin, 1983). The total production of mercury for use in industrialization has greatly increased during this century. It is mainly used in the manufacturing of electrical equipment and in the electrolytic production of chlorine and caustic soda (Moore and Ramamoorthy, 1984). After the outbreak of Minamata Disease (Kitamura, 1968; Förstner and Wittmann, 1981), the consequences of mercury contamination in the aquatic environment came under closer scrutiny. In Taiwan, estuarine seawater polluted with mercury has been surveyed in the Lu-Ar-

*To whom correspondence should be addressed.
Man River, Tainan (Chen and Lin, unpublished data). Whereas many studies point out that sub-lethal concentrations of mercury have minimal effects on organisms in optimum conditions, it becomes more toxic under stress conditions with extreme temperatures and salinity (Vernberg and Vernberg, 1972; Jones, 1973; Nelson et al., 1977; Denton and BurdonJones, 1981). Interestingly, little is known about the toxic effects of mercury on the hard clam, Meretrix lusoria. The present study was therefore undertaken to determine the effect of mercury on the mortality and embryonic development of the hard clam, Meretrix lusoria, at different salinities.

\section{MATERIALS AND METHODS}

Adult and juvenile hard clams, Meretrix lusoria, were obtained from a commercial shellfish farm located in the Taishi area and were acclimatized to laboratory tanks at different salinities $(10,20$ and $30 \mathrm{ppt}$ ) for one week before use. The adult clams used had an average shell length of $2.97 \pm 0.15 \mathrm{~cm}$, shell height of $2.47 \pm 0.14 \mathrm{~cm}$ and wet weight of $6.552 \pm 0.963 \mathrm{~g}$. The juveniles tested had an average shell length of $1.06 \pm 0.08 \mathrm{~cm}$, shell height of $0.88 \pm 0.07 \mathrm{~cm}$ and wet weight of $2.777 \pm 0.144 \mathrm{~g}$. During the period of acclimation, the clams were not fed but supplied with aeration. Water temperatures were maintained at $25 \pm 1{ }^{\circ} \mathrm{C}$.

Mercury stock solutions were prepared by dissolving $1.36 \mathrm{~g}$ of mercuric chloride $\left(\mathrm{HgCl}_{2}\right.$, Merck reagent grade) in 11 of distilled water containing $1 \mathrm{ml}$ concentrated $\mathrm{HNO}_{3}$ to make $1000 \mathrm{mg} / \mathrm{l} \mathrm{Hg}$. Before commencing the experiments, they were diluted to desired concentrations using filtered seawater $(0.45-\mu$ Millipore filter). For adult clams, the nominal 
concentrations studied were $0.125,0.25,0.5,1.0,2.0$ and $4.0 \mathrm{mg} / \mathrm{l} \mathrm{Hg}$. Thirteen adult clams were placed into each of a series of 3-I polypropylene containers having different $\mathrm{Hg}$ concentrations. For juvenile clams, triplicate cultures were also established for each test concentration and control, with nominal concentrations of $0.1,0.2,0.4,0.8$ and $1.6 \mathrm{mg} / 1 \mathrm{Hg}$. Ten clams were placed into each of a series of $1-1$ beakers, similar to those used for the adults. Iriplicate cultures were established for each test concentration and triplicate untreated cultures served as controls. In the toxicity test, static method without aeration was conducted throughout this study and all test solutions were renewed daily (Buikema et al., 1982; Apha et al., 1985). During the experiment, the clams were not fed. In all test solutions, water temperatures were maintained at $25 \pm 1^{\circ} \mathrm{C}$, dissolved oxygen and $\mathrm{pH}$ varied from 3.5 to $7.0 \mathrm{mg} / 1$ and from 7.75 to 8.36 , respectively. Death was determined when both valves continued to gape and showed no sign of response after mechanical agitation.

Adult clams were induced to spawn in natural seawater in the laboratory by thermal stimulation (Chen and Lyuu, 1983). After the clams began spawning, the fertilized eggs were collected and transferred to filtered seawater. To determine the toxic effect of mercury on embryonic development, $1 \mathrm{ml}$ filtered seawater containing fertilized eggs (about 80 ) was placed into each of a series of tubes containing $5 \mathrm{ml}$ filtered seawater ( $15 \mathrm{ppt}$ salinity), with various mercury concentrations, at $26 \pm 1{ }^{\circ} \mathrm{C}$. The final nominal concentrations were $2.5,5.0,10.0,20.0$ and $40.0 \mu \mathrm{g} / 1 \mathrm{Hg}$. Four replicates of each test concentration were used, and four untreated cultures served as controls. A static test was conducted throughout this study and initiated within $2 \mathrm{hr}$ after eggs were fertilized. Tests were terminated after $30 \mathrm{hr}$ because the embryonic development was completed by this time, the embryos having developed into straight hinged, D-stage larvae. At the end of the experiment, all test solutions from each tube were collected, and fixed with $10 \%$ buffered formalin. The samples were examined immediately under a microscope and the number of embryos that had developed into D-larvae were counted. The results of the counts of samples from four replicate cultures were averaged and the final result expressed as a percentage of the average number in control cultures.

The dose response of test organisms obtained from replicate tanks of each test solution was assessed by the method of probit analysis (Finney, 1971). The $\mathrm{LC}_{50}$ (median lethal concentration) values and $\mathrm{EC}_{50}$ (median effective concentration, the criterion being failure to reach $\mathrm{D}$-stage larvae) values of $\mathrm{Hg}$, with their $95 \%$ confidence limits, were calculated using a microcomputer program (Trevors and Lusty, 1985). The program was based on the method described by Hubert (1980). With this program, the estimated probit line and the result of a Chi-square test for goodness of fit were computed. In order to compare the survival time at fixed mercury concentrations between different life stages, the time to $50 \%$ mortality, expressed as $\mathrm{LT}_{50}$, was also calculated.

\section{RESULTS AND DISCUSSION}

Acute toxicity of mercury to adult hard clams in different salinities is shown in Fig. 1. As might be expected, the higher the mercury concentration, the higher the mortality. Toxicity to the animals is also found to be affected by different salinities; mortality increases with increasing salinities. The same is true for juvenile hard clams exposed to mercury in various salinities. However, salinity's effect on the toxicity of mercury is clearer in adult hard clams than juvenile animals, especially for adults in the $10 \mathrm{ppt}$ salinity range.

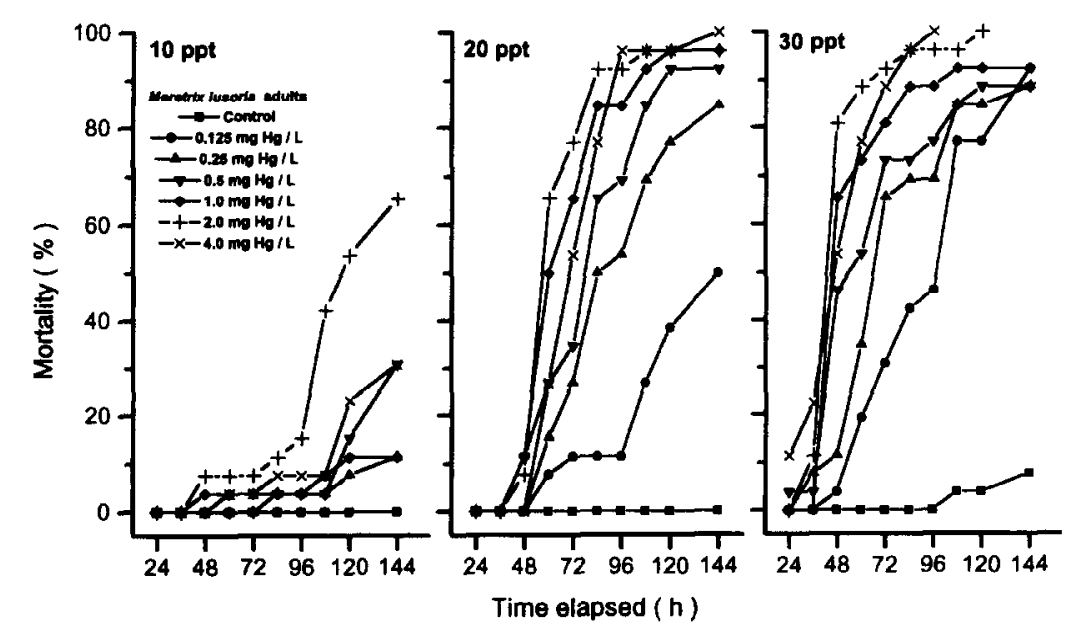

Fig. 1. Percentage mortality of Meretrix lusoria adults exposed to different mercury concentrations in three salinities. 


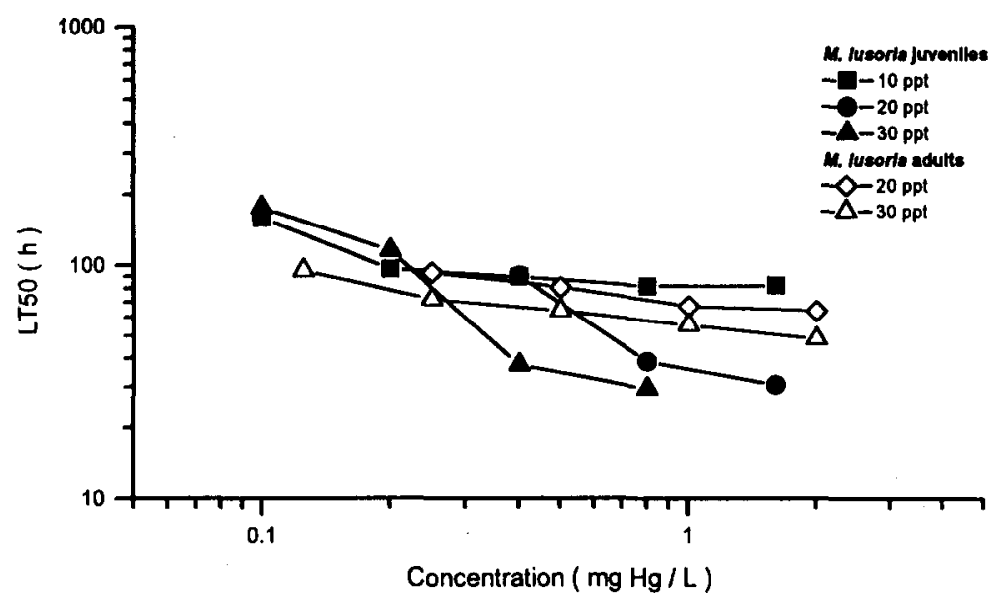

Fig. 2. Acute toxicity of mercury to Meretrix lusoria juveniles and adults in different salinities.

It is commonly believed that animals of different ages have differing susceptibility to pollutants, younger animals being more sensitive to pollution than adults (Chen, 1980). Figure 2 shows the comparison of mercury toxicity to juveniles and adults by plotting their $\mathrm{LT}_{50}$ values against the mercury concentration used. It can be seen that the adults are more resistant to mercury poisoning at concentrations above $0.4 \mathrm{mg} / \mathrm{l} \mathrm{Hg}$ in the same salinity. However, inversely, at low concentrations of $0.4 \mathrm{mg} / \mathrm{l} \mathrm{Hg}$ or below, juvenile hard clams can survive longer than adults clam. The $\mathrm{LC}_{50}$ and their $95 \%$ confidence limits for embryo, juvenile and adult hard clams are shown in (Table 1).

The hard clam is a euryhaline species; its optimal salinity for survival and growth decrease with advanced life stages. Adult hard clams prefer low salinities of 10-15 ppt to normal salinity, while juvenile clams need optimal salinity of 20 ppt (Chen, 1984; Yang and Ting, 1984). These facts suggest that a stressful condition may accelerate the toxicity of mercury. Dillon (1977) reported that mercury appeared to be much less toxic to euryhaline clams,
Rangia cuneata, acclimated in 2 ppt salinity than those acclimated in $15 \mathrm{ppt}$ salinity while the reason for being less toxic in low salinity is not well understood. Dillon and Neff (1978) suggested that a decrease of toxicity in brackish water is due to the enhanced ability to depurate mercury in the body.

The relationship between probit of mortality and log concentration at various exposure times in different salinities and life stages for hard clams was calculated and is listed in Table 2. All linear regression lines estimated are significant from the chisquare test with a high correlation coefficient, suggesting that they are highly satisfactory, as expressed by Trevors and Lusty (1985). There is a great difference in slopes between both juvenile and adult groups, regardless of different salinities used and time of exposure to mercury. This finding confirms the fact that adults are more tolerant of mercury poisoning than juveniles. When concentration of mercury increases, it has a more serious effect on survival time of juveniles than of adults (Fig. 2).

Resistance to mercury toxicity with low salinity in Meretrix lusoria and Rangia cuneata (Dillon, 1977)

Table 1 . The $\mathrm{LC}_{50}$ and their $95 \%$ confidence limits of mercury (as $\mathrm{HgCl}_{2}$ ) for the hard calm, Mererix lusoria, in different salinities at $25 \pm 1^{\prime \prime} \mathrm{C}$

\begin{tabular}{|c|c|c|c|c|c|c|}
\hline \multirow[b]{3}{*}{ Time (hr) } & \multicolumn{6}{|c|}{ Concentration $(\mathrm{mg} / \mathrm{l} \mathrm{Hg})(\mathrm{ppt})$} \\
\hline & \multicolumn{2}{|r|}{10} & \multicolumn{2}{|r|}{20} & \multicolumn{2}{|r|}{30} \\
\hline & $L C_{50}$ & $95 \% \mathrm{CL}$ & $\mathrm{LC}_{50}$ & $95 \% \mathrm{CL}$ & $\mathrm{LC}_{50}$ & $95 \% \mathrm{CL}$ \\
\hline \multicolumn{7}{|l|}{ Juvenile } \\
\hline 24 & & & & & 0.991 & $0.760-1.290$ \\
\hline 48 & & & 0.799 & $0.663-0.964$ & 0.400 & $0.329-0.488$ \\
\hline 72 & & & 0.435 & $0.378-0.500$ & 0.248 & $0.210-0.294$ \\
\hline 96 & 0.328 & $0.218-0.493$ & 0.392 & $0.344-0.447$ & 0.194 & $0.169-0.223$ \\
\hline 120 & 0.108 & $0.075-0.156$ & 0.351 & $0.305-0.404$ & 0.175 & $0.15 !-0.202$ \\
\hline 144 & & & 0.275 & $0.231-0.328$ & 0.136 & $0.113-0.163$ \\
\hline 168 & & & 0.213 & $0.174-0.259$ & 0.115 & $0.090-0.147$ \\
\hline \multicolumn{7}{|l|}{ Adult } \\
\hline 48 & & & & & 0.783 & $0.572-0.952$ \\
\hline 60 & & & 1.121 & $0.738-1.703$ & 0.428 & $0.311-0.590$ \\
\hline 72 & & & 0.701 & $0.496-0.989$ & 0.209 & $0.128-0.340$ \\
\hline 96 & & & 0.341 & $0.244-0.476$ & 0.140 & $0.078-0.235$ \\
\hline 120 & 5.071 & $2.078-12.370$ & 0.135 & $0.072-0.235$ & & \\
\hline 144 & 2.993 & $1.517-5.928$ & 0.099 & $0.054-0.184$ & & \\
\hline
\end{tabular}


Table 2. Relationship between probit of mortality $(Y)$ and $\log$ concentration of mercury as $\mathrm{mg} / \mathrm{l} \mathrm{Hg}(X)$ at various exposure time, salinities and sizes for the hard clam, Meretrix lusoria

\begin{tabular}{|c|c|c|c|c|c|}
\hline Salinity & Time (hr) & $Y=a+b X$ & $N$ & $R^{2}$ & $\chi^{2}$ \\
\hline \multicolumn{6}{|l|}{$\begin{array}{r}D \text {-larvae } \\
15 \mathrm{ppt}\end{array}$} \\
\hline & 30 & $Y=3.3910+0.2437 X$ & 3 & 0.9847 & 1.1517 \\
\hline \multicolumn{6}{|l|}{$\begin{array}{l}\text { Juvenile } \\
10 \mathrm{ppt}\end{array}$} \\
\hline & 96 & $Y=5.7536+1.5556 X$ & 3 & 0.9583 & 0.3834 \\
\hline & 120 & $Y=7.3300+2.4080 X$ & 4 & 0.9268 & 1.9546 \\
\hline \multicolumn{6}{|c|}{ 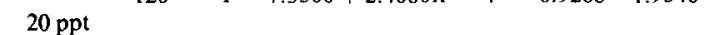 } \\
\hline & 48 & $Y=5.3612+3.7136 X$ & 3 & 0.8772 & 2.6191 \\
\hline & 72 & $Y=7.1828+6.0331 X$ & 3 & 0.9583 & 2.1197 \\
\hline & 96 & $Y=7.6588+6.5366 X$ & 3 & 0.9987 & 0.2634 \\
\hline & 120 & $Y=7.7267+5.9949 X$ & 3 & 0.9847 & 0.6431 \\
\hline & 144 & $Y=7.5338+4.5222 X$ & 3 & 0.9635 & 1.0086 \\
\hline & 168 & $Y=7.3181+3.4462 X$ & 3 & 0.9051 & 1.9533 \\
\hline \multicolumn{6}{|l|}{$30 \mathrm{ppt}$} \\
\hline & 24 & $Y=5.0109+2.5234 X$ & 4 & 0.9513 & 1.3658 \\
\hline & 48 & $Y=6.3383+3.3653 X$ & 4 & 0.9693 & 1.9153 \\
\hline & 72 & $Y=7.7184+4.4937 X$ & 4 & 0.8847 & 3.1381 \\
\hline & 168 & $Y=8.2069+3.4120 X$ & 3 & 0.7864 & 4.2277 \\
\hline \multicolumn{6}{|l|}{ Adult } \\
\hline & 120 & $Y=4.1685+1.1794 X$ & 3 & 0.8146 & 1.7492 \\
\hline & 144 & $Y-4.4233+1.2093 X$ & 3 & 0.7589 & 2.2663 \\
\hline \multicolumn{6}{|l|}{$20 \mathrm{ppt}$} \\
\hline & 60 & $Y=4.9217+1.5807 X$ & 5 & 0.9912 & 0.2488 \\
\hline & 72 & $Y=5.2511+1.6257 X$ & 5 & 0.9693 & 1.1038 \\
\hline & 96 & $Y=5.8592+1.8393 X$ & 6 & 0.9161 & 4.4780 \\
\hline & 120 & $Y=6.3195+1.5983 X$ & 5 & 0.9125 & 2.3626 \\
\hline & 144 & $Y=6.8872+1.8810 X$ & 4 & 0.8967 & 1.2960 \\
\hline \multicolumn{6}{|l|}{$30 \mathrm{ppt}$} \\
\hline & 48 & $Y=5.3092+2.3443 X$ & 5 & 0.9625 & 2.0751 \\
\hline & 60 & $Y=5.6275+1.704 \mid X$ & 5 & 0.9978 & 0.0678 \\
\hline & 72 & $Y=5.9755+1.4334 X$ & 5 & 0.9074 & 1.9803 \\
\hline & 84 & $Y=6.2250+1.5230 X$ & 5 & 0.9579 & 1.1651 \\
\hline & 96 & $Y=6.2436+1.4560 X$ & 5 & 0.9749 & 0.4610 \\
\hline
\end{tabular}

$N$ : number of nominal time for calculation.

$R^{i}$ : coefficient of correlation.

differs from that in other bivalves. Nelson et al. (1977) demonstrated that the survival of juvenile bay scallops, Argopecten irradians, was significantly affected by mercury, as well as salinity. In that study, juvenile bay scallops, considered a stenohaline and cold water species, were reared at $20 \pm 2{ }^{\circ} \mathrm{C}$ and $25 \pm 2$ ppt salinity for about 3 months prior to testing. Results showed that low salinity alone enhanced the toxicity of low concentrations of mercury. High temperature and low salinity also acted synergistically with mercury to increase mortality. Therefore, the lowest concentration of mercury that caused 96-hr $\mathrm{LC}_{50}$ occurred at the highest temperature $\left(25^{\circ} \mathrm{C}\right)$ and lowest salinity (15 ppt) tested (Table 3 ). It is generally accepted that, under optimal conditions, the toxicity of a pollutant to aquatic animals could be reduced to a minimum. Bryan (1971) suggested that the increased toxicity of heavy metals to marine organisms under unfavorable environmental conditions be related to changing rates of absorption. Furthermore, this rate can be varied with experimental conditions, species tested, and life stage of the test animal (Fowler et al., 1978; Langston, 1982).

Toxic effects of mercury chloride on other bivalve species are summarized in Table 3. As mentioned previously, Nelson et al. (1976) reported that at $20 \pm 1^{\circ} \mathrm{C}$ in natural seawater $(25 \pm 2$ ppt salinity $)$, the 96-hr $\mathrm{LC}_{50}$ value and their $95 \%$ confidence limits were 89 and $54-147 \mu \mathrm{g} / 1 \mathrm{Hg}$, respectively, for juvenile bay scallops, Argopecten irradians. For Mytilus edulis, Strömgren (1982) recorded that acute lethal effects were observed at $25 \mu \mathrm{g} / 1 \mathrm{Hg}$ within $24 \mathrm{hr}$, and $\mathrm{EC}_{50}$ for growth at about $0.3-0.4 \mu \mathrm{g} / \mathrm{Hg}$. However, Martin et al. (1975) recorded a relatively high tolerance of Mytilus edulis to inorganic mercury, with $7 \mathrm{~d}-\mathrm{LC}_{50}$ at $150 \mu \mathrm{g} / \mathrm{l} \mathrm{Hg}$. The 96-hr $\mathrm{LC}_{50}$ value for the hooked mussel, Brachiodontes recurous, calculated from actual exposure mercury concentrations, was $27 \mu \mathrm{g} / 1$ (Green et al., 1975). Mohan et al. (1986) reported that the $96-\mathrm{hr} \mathrm{LC}_{50}$ values, and their $95 \%$ confidence limits, of the tropical green mussel, Perna viridis, exposed to mercury were 230 and $210-250 \mu \mathrm{g} / \mathrm{l} \mathrm{Hg}$, respectively. A concentration of $29-38 \mu \mathrm{g} / \mathrm{l} \mathrm{Hg}$ reduced the byssalthread production by $50 \%$ during both light and dark phases. Oxygen uptake in Perna viridis decreased with increasing mercury levels, concentrations between 40 and $50 \mu \mathrm{g} / 1$ reducing uptake by $50-60 \%$. The $120-\mathrm{hr}$ I. $C_{50}$ for freshwater mussels, Lamellidens marginalis, was $2754-3311 \mu \mathrm{g} / \mathrm{l} \mathrm{Hg}$ (Sivaramakishna et al., 1991). Adult oysters, Ostrea edulis, were exposed to mercury and $50 \%$ died with $48 \mathrm{hr}$ at $4200 \mu \mathrm{g} / 1$ (Conner, 1972). The 6-10 day $\mathrm{LC}_{50}$ for short-necked clams, Venus japonica, was $100-500 \mu \mathrm{g} / \mathrm{l} \mathrm{Hg}$ (Irukayama, 1962). The $60-\mathrm{d} \mathrm{LC}_{50}$ for three species of bivalve molluscs of the Caspian Sea, Mytilaster lineatus, Didacna trigonoides and Monodacna caspia, was $5-10 \mu \mathrm{g} / \mathrm{l} \mathrm{Hg}$. Therefore, in this case, no significant differences between species were noted (Patin, 1982). Olson and Harrel (1973) found that $8700 \mu \mathrm{g} / 1$ mercury was needed to attain $96-\mathrm{hr} \mathrm{LC}_{50}$ of the estuarine clam, Rangia cuneata, a value considerably higher than that affecting other bivalve species. Therefore, in the present study, the hard clam, Meretrix lusoria, may be considered as an organism which is very sensitive to mercury poisoning.

The earlier developmental stages of marine biota have repeatedly been found to be more sensitive to environmental pollutants than their adult counterparts. The toxicity of mercuric chloride to the hard clam D-stage larvae at $28^{\circ} \mathrm{C}$ in $15 \mathrm{ppt}$ salinity is shown in Fig. 3. Statistical analysis indicated that the average percentages of $\mathrm{D}$-stage larvae had a decaying exponential relationship with mercury concentrations. The percentages of the clam embryos developing into D-stage larvae after $30 \mathrm{hr}$ in controls, 2.5 , 5.0, 10.0 and $20 \mu \mathrm{g} / 1 \mathrm{Hg}$ were $44 \pm 6,32 \pm 3,23 \pm 4$, $19 \pm 6$ and $3 \pm 2 \%$, respectively. All embryos exposed to $40 \mu \mathrm{g} / \mathrm{l} \mathrm{Hg}$ and above died within $30 \mathrm{hr}$. In the control, $44 \%$ of hatched embryos developed into D-stage larvae within $30 \mathrm{hr}$, while those exposed to $20 \mu \mathrm{g} / 1 \mathrm{Hg}$ were still in the trochophore stage. Furthermore, most of the retarded larvae developed into

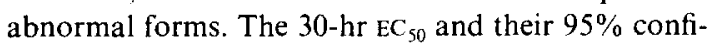
dence limits for the clam embryos were obtained as low as 4.6 and $3.9-5.3 \mu \mathrm{g} / \mathrm{l} \mathrm{Hg}$, respectively.

Wisely and Blick (1967) reported that when larvae of the mussel, Mytilus edulis lanulatus, and the oyster, 
Table 3. Toxicity of mercury (as $\mathrm{HgCl}_{2}$ ) to other bivalve molluses

\begin{tabular}{|c|c|c|c|}
\hline Organism & $\begin{array}{l}\text { Water quality } \\
\text { parameters }\end{array}$ & $\begin{array}{c}\text { Length of } \mu \mathrm{g} / \mathrm{l} \mathrm{Hg} \text { exposure } \\
(95 \% \mathrm{CL})\end{array}$ & Authors \\
\hline $\begin{array}{l}\text { Argopecten irradians } \\
\text { Shell height } \\
20-30 \mathrm{~mm}\end{array}$ & $\begin{array}{l}\mathrm{pH} 7.0-8.0 \\
20 \pm 1^{\circ} \mathrm{C} \\
25 \pm 2 \mathrm{ppt}\end{array}$ & 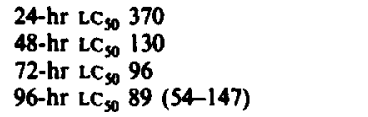 & Nelson et al. (1976) \\
\hline $\begin{array}{l}\text { Argopecten irradians } \\
\text { Shell height } \\
16-27 \mathrm{~mm}\end{array}$ & $\begin{array}{l}{ }^{\circ} \mathrm{C} \times \mathrm{ppt} \\
15 \times 15 \\
15 \times 20 \\
15 \times 25 \\
20 \times 15 \\
20 \times 20 \\
20 \times 25 \\
25 \times 15 \\
25 \times 20 \\
25 \times 25\end{array}$ & $\begin{array}{l}\text { 96-hr LC } \mathrm{LC}_{90} 83(78-89) \\
96-\mathrm{hr} \mathrm{LC}_{50} 118(110-126) \\
96-\mathrm{hr} \mathrm{LC}_{50} 112(105-120) \\
96-\mathrm{hr} \mathrm{LC}_{50} 78(72-84) \\
96-\mathrm{hr} \mathrm{LC}_{90} 128(119-138) \\
96-\mathrm{hr} \mathrm{LC}_{50} 122(114-131) \\
96-\mathrm{hr} \mathrm{LC}_{50} 54(48-60) \\
96-\mathrm{hr} \mathrm{LC}_{50} 132(120-145) \\
96-\mathrm{hr} \mathrm{LC}_{50} 115(105-126)\end{array}$ & Nelson et al. (1977) \\
\hline $\begin{array}{l}\text { Brachiodantes recurvus } \\
\text { Larvae }\end{array}$ & $\begin{array}{l}19-20^{\circ} \mathrm{C} \\
19-20 \mathrm{ppt}\end{array}$ & $2-\mathrm{hr} \operatorname{LC}_{30} 180,000$ & Wisely and Blick (1967) \\
\hline $\begin{array}{l}\text { Crassostrea gigas } \\
\text { Embryos }\end{array}$ & $27^{\circ} \mathrm{C}$ & $\begin{array}{l}\text { Affected } 32 \\
\text { Not affected } 10\end{array}$ & Okubo and Okubo (1962) \\
\hline $\begin{array}{l}\text { Crassostrea gigas } \\
\text { Embryos }\end{array}$ & $\begin{array}{l}\text { pH } 8.1 \pm 0.2 \\
\text { DO } 6.5-8.0 \mathrm{mg} / 1 \\
20 \pm 1{ }^{\circ} \mathrm{C} \\
33.7 \pm 0.1 \mathrm{ppt}\end{array}$ & $48-\mathrm{hr} \mathrm{EC}_{\mathrm{s0}} 6.7 \pm 1.55$ & Martin et al. (1981) \\
\hline $\begin{array}{l}\text { Crassostrea gigas } \\
\text { Embryos }\end{array}$ & $\begin{array}{l}\text { pH } 8.1 \pm 0.2 \\
20 \pm 1{ }^{\circ} \mathrm{C} \\
33.7 \pm 0.1 \mathrm{ppt} \\
\mathrm{DO} 6.5-8.0 \mathrm{mg} / 1\end{array}$ & $48-h r \mathrm{EC}_{90} 5.7$ & Glickstein (1978) \\
\hline $\begin{array}{l}\text { Crassostrea gigas } \\
\text { Larvae }\end{array}$ & & Morphological abnormalities 27 & Woelke (1965) \\
\hline $\begin{array}{l}\text { Crassostrea virginica } \\
\text { Embryos }\end{array}$ & $\begin{array}{l}26 \pm 1^{\circ} \mathrm{C} \\
25 \mathrm{ppt}\end{array}$ & $48-\mathrm{hr} L C_{50} 5.6(4.2-6.8)$ & Calabrese et al. (1973) \\
\hline $\begin{array}{l}\text { Crassostrea virginica } \\
\text { Embryos }\end{array}$ & & 48-hr LC SO $_{\$ 0} 10.2$ & Macinnes and Calabrese (1978) \\
\hline $\begin{array}{l}\text { Crassostrea virginica } \\
\text { Larvae } \\
2 \text { days old }\end{array}$ & $\begin{array}{l}\mathrm{pH} 7.0-8.5 \\
25 \pm 1{ }^{\circ} \mathrm{C} \\
24 \pm 2 \mathrm{ppt}\end{array}$ & $12-d L C_{s 0} 12.0(3.3-20.7)$ & Calabrese et al. (1977) \\
\hline Didacna trigonoides & $60-\bar{d}$ LC $_{50} 5-10$ & & Patin (1982) \\
\hline $\begin{array}{l}\text { Lamellidens marginalis } \\
\text { Weight } \\
15 \pm 18\end{array}$ & $\begin{array}{l}\mathrm{pH} 7.6 \pm 0.2 \\
\text { Total hardness } 100 \pm 5 \mathrm{mg} / \mathrm{CaCO} \\
28 \pm 1^{\circ} \mathrm{C} \\
\text { DO } 5.7 \pm 0.4 \mathrm{mg} / 1 \\
\text { Freshwater }\end{array}$ & $120-\mathrm{hr} L \mathrm{LC}_{50} 2754-331 \mathrm{l}$ & Sivaramakrishna et al. (1991) \\
\hline $\begin{array}{l}\text { Mercenaria mercenaria } \\
\text { Embryos }\end{array}$ & $\begin{array}{l}\text { pH } 7.0-8.5 \\
26 \pm 1{ }^{\circ} \mathrm{C} \\
25 \mathrm{ppt}\end{array}$ & $42-48-\mathrm{hr} l \mathrm{CC}_{50} 4.8(3.8-5.6)$ & Calabrese and Nelson (1974) \\
\hline $\begin{array}{l}\text { Mercenearia mercenaria } \\
\text { Larvae } \\
2 \text { days old }\end{array}$ & $\begin{array}{l}\mathrm{pH} 7.0-8.5 \\
25 \pm 1{ }^{\circ} \mathrm{C} \\
24 \pm 2 \mathrm{ppt}\end{array}$ & $8-10-d \operatorname{LC}_{50} 14.7(4.0-25.4)$ & Calabrese et al. (1977) \\
\hline $\begin{array}{l}\text { Monodacna caspia } \\
\text { Mytilaster lineatus }\end{array}$ & & $\begin{array}{l}60-d L C_{s 0} s-10 \\
60-d L C_{s 0} s-10\end{array}$ & $\begin{array}{l}\text { Patin (1982) } \\
\text { Patin (1982) }\end{array}$ \\
\hline $\begin{array}{l}\text { Mytilus edulis plamulatus } \\
\text { Larvae } \\
14 \text { days old }\end{array}$ & $\begin{array}{l}\mathrm{pH} 7.8-8.2 \\
18 \pm 2^{\circ} \mathrm{C} \\
19-20 \mathrm{ppt}\end{array}$ & $2-h r L C_{s 0} 13,000$ & Wisely and Blick (1967) \\
\hline $\begin{array}{l}\text { Mytilus edulis } \\
\text { Embryos }\end{array}$ & $13-17^{\circ} \mathrm{C}$ & $\begin{array}{l}\text { Affected } 32 \\
\text { Not affected } 10\end{array}$ & Okubo and Okubo (1962) \\
\hline $\begin{array}{l}\text { Mytilus edulis } \\
\text { Embryos }\end{array}$ & $\begin{array}{l}\text { pH } 8.1 \pm 0.2 \\
\text { DO } 6.5-8.0 \mathrm{mg} / 1 \\
17 \pm 1{ }^{\circ} \mathrm{C} \\
33.79 \pm 0.07 \mathrm{ppt}\end{array}$ & $48-h r \mathrm{EC}_{90} 5.8 \pm 1$ & Martin et al. (198I) \\
\hline $\begin{array}{l}\text { Mytilus edulis } \\
\text { Shell length } \\
12-29 \mathrm{~mm}\end{array}$ & $\begin{array}{l}\text { Flow rate }(1 \mathrm{l} / \mathrm{min}) \\
8.5-8.7^{\circ} \mathrm{C} \\
33.8 \mathrm{ppt}\end{array}$ & $\begin{array}{l}24-h r L^{2} C_{s 0} 25 \\
5-\text { EC }_{50} 0.3-0.4 \\
\text { (For growth) }\end{array}$ & Strömgren (1982) \\
\hline $\begin{array}{l}\text { Mytilus edulis } \\
\text { Ostrea edulis }\end{array}$ & $15^{\circ} \mathrm{C}$ & $7-d \operatorname{LC}_{50} 150$ & $\begin{array}{l}\text { Martin ef al. (1975) } \\
\text { Conner (1972) }\end{array}$ \\
\hline $\begin{array}{l}\text { Larvac } 1-3 \text { days old } \\
\text { Adults }\end{array}$ & & $\begin{array}{l}48-h r L C_{50} 1-3.3 \\
48-h r \quad L C_{50} 4200\end{array}$ & \\
\hline $\begin{array}{l}\text { Perna viridis } \\
\text { Shell length } \\
20-25 \mathrm{~mm}\end{array}$ & $\begin{array}{l}\text { pH } 8.15-8.30 \\
28 \pm 1{ }^{\circ} \mathrm{C} \\
\text { (For byssal-threaded production) } \\
\text { (For oxygen uptake) }\end{array}$ & $\begin{array}{l}48-h r L C_{S 0} 1000 \\
60-h r L C_{50} 520 \\
84-h r L C_{50} 230 \\
E_{S 0} 29-38 \\
E_{50-60} 40-50\end{array}$ & Mohan et al. (1986) \\
\hline Rangia cunneata & $\begin{array}{l}5.5 \mathrm{ppt} \\
22 \mathrm{ppt}\end{array}$ & 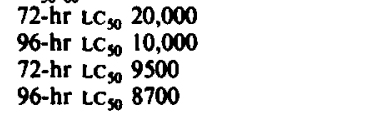 & Olson and Harrel (1973) \\
\hline Venus japonica & $\begin{array}{l}2 \mathrm{ppt} \\
15 \mathrm{ppt}\end{array}$ & $\begin{array}{l}72-h r L_{50} 242(224-262) \\
96-h r \text { LC } 122(114-130) \\
72-h r L C_{50} 57(37-89) \\
96-h r \text { LC } 58(50-68) \\
6-10-d \text { LC } 50100-500\end{array}$ & Irukayama et al. (1962) \\
\hline
\end{tabular}




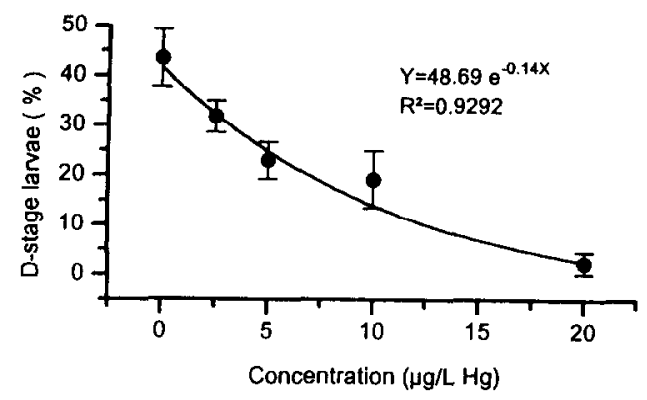

Fig. 3. The percentages of Meretrix lusoria embryos developing into D-stage larvae after $30 \mathrm{hr}$ of exposure to mercury.

Crassostres commericalis, were exposed to mercury, $50 \%$ died within $2 \mathrm{hr}$ at 13.0 and $180.5 \mathrm{mg} / \mathrm{l}$, respectively. It was concluded that this high resistance was due to the ability of these organisms to withdraw their bodies into their shells, thereby reducing the penetration of the toxic material into the tissues. These concentrations were considerably higher than those tested in the larval studies of Mytilus edulis (Okubo and Okubo, 1962; Martin et al., 1981), Mercenaria mercenaria (Calabrese and Nelson, 1974; Calabrese et al., 1977), Crassostrea viginica (Calabrese et al., 1973; Calabrese and Nelson, 1974; MacInnes and Calabrese, 1978), Crassostrea gigas (Okubo and Okubo, 1962; Woelke, 1965; Glickstein, 1978; Martin et al., 1981), Ostrea edulis (Conner, 1972) and Merertrix lusoria (the present study). This indicates that variation of mercury toxicity in bivalves depends on the species, developmental stage, animal size, adaptive ability, amount of accumulation, as well as environmental factors such as temperature, $\mathrm{pH}$, and water hardness.

In assessing the environmental hazard of pollutants and protecting the natural aquatic resources, 'safe' concentrations have been estimated by multiplying the $96-\mathrm{hr} \mathrm{LC}_{50}$ by a factor of $0.1-0.01$ as suggested by Sprague (1971) and FAO (1977). We calculated the safe level to be $1.9-3.9 \mu \mathrm{g} / \mathrm{H} \mathrm{Hg}$ based on the $96-\mathrm{hr}$ $\mathrm{LC}_{50}$ value of the juvenile, with an application factor of 0.01 (Sprague, 1971) in $30-10 \mathrm{ppl}$ salinity. Environmental perturbations, which affect successful larval development, can potentially have serious detrimental effects on populations and ecosystems. Such effects would be subtle, causing decreased recruitment to exisiting populations. Bioassays, utilizing embryos and larvae, are potentially very sensitive tools for the identification of environmental stress. Goldberg (1963) reported that the average mercury concentration in unpolluted surface water was about $0.03 \mu \mathrm{g} / \mathrm{l}$. FAO (1970) reported that surface seawater containing more than $0.2 \mu \mathrm{g} / \mathrm{l} \mathrm{Hg}$ should be considered to be polluted with mercury. Therefore, we suggest that a more sensitive estimate of the 'safe level' be $0.046(0.039-0.053) \mu \mathrm{g} / \mathrm{l} \mathrm{Hg}$, based on the most sensitive embryological stage, with an application factor of 0.01 . This biologically safe level of mercury is similar to the levels of criterion $(<0.05 \mu \mathrm{g} / \mathrm{l} \mathrm{Hg}$ for freshwater organisms, $<0.1 \mu \mathrm{g} / \mathrm{l}$ $\mathrm{Hg}$ for marine organisms) recommended by Klein et al. (1979).

Acknowledgements - This research is financially supported by both the National Science Council and Council of Agriculture. We are very grateful to Y. H. Chou for help sampling the clams. Many thanks are also due to J. Peters and S. MacLeod for kindly reading the manuscript.

\section{REFERENCES}

American Public Health Association, American Water Works Association and Water Pollution Control Federation (1985) Standard Methods for the Examination of Water and Wastewater (16th Edn). American Public Health Association. Washington, D.C.

Baier R., Wojnowich W. J. and Petrie L. (1975) Mercury loss from culture media. Analyt. Chem. 47, 2464-2467.

Buikema A. L. Jr, Niedertehner R. R. and Cairns J. Jr (1982) Biological monitoring part IV-toxicity testing. Water Res. 16, 239-262.

Calabrese A., Collier R. S., Nelson D. A. and Macinnes J. R. (1973) The toxicity of heavy metals to embryos of the American oyster, Crassostrea virginica. Mar. Biol. 18, 162-166.

Calabrese A., MacInnes J. R., Nelson D. A. and Miller J. E. (1977) Survival and growth of bivalve larvae under heavy-metal stress. Mar. Biol. 41, 179-184.

Calabrese A. and Nejson D. A. (1974) Inhibition of embryonic development of the hard clam, Mercenaria mercenaria, by heavy metals. Bull. Envir. Contam. Toxicol. 11, 92-97.

Chen H. C. (1980) Acute toxicity of some heavy metals to the prawn Palaemon elegans. J. Mar. Sci-Biological Research Institute of Marime Science and Department of Marine Science, Chinese Culture University No. 26, 1-16.

Chen H. C. (1984) Recent innovations in cultivation of edible mollusca in Taiwan, with special reference to the small abalone, Haliotis diversicolor, and the hard clam, Meretrix lusoria. Aquaculture 39, 11-27.

Chen H. C. and Chin T. S. (1983) Studies on the accumulation and elimination of mercury in the oyster, Crassostrea gigas. J. Fish. Soc. Taiwan 10(2), 42-47.

Chen H. C. and Lyuu R. Y. (1983) Studies on the artificial propagation of the hard clam, Meretrix lusoria, induced spawning, embryonic development and larval growth. J. mar. Sci--Biological Research Institute of Marine Science and Department of Marine Science, Chinese Culture University No. 28, 1-16.

Connor P. M. (1972) Acute toxicity of heavy metals to some marine larvae. Mar. Pollut. Bull. 3, 190-192.

Denton G. R. W. and Burdon-Jones C. (1981) Influence of temperature and salinity of the uptake, distribution and depuration of mercury, cadmium and lead by the blacklip oyster, Saccostrea echinata. Mar. Biol. 64, 317-326.

Dillon T. M. (1977) Mercury and the estuarine marsh clam, Rangia cuneata Gray. I. Toxicity. Archs. Environ. Contam. Toxicol. 6, 249-255.

Dillon T. M. and Neff J. M. (1978) Mercury and the estuarine marsh clam, Rangia cuneata Gray. II. Uptake, tissue distribution and depuration. Mar. Environ. Res. 1, $67-77$.

FAO (1970) Report of the seminars on methods of detection measurement and monitoring of pollutants in the marine environments. Fish. Rept No. 99, suppl. 1.

FAO (1977) Bases for selecting biological tests to evaluate marine pollution. FAO Fish Tech. Paper 164 (part 4), $1-19$.

Finney D. J. (1971) Probit Analysis (3rd Edn), 333 pp. Cambridge University Press, London. 
Förstner U. and Wittmann G. T. W. (1981) Metal Pollution in the Aquatic Environment, 486 pp. Springer, New York.

Fowler S. W., Heyraud M. and La Rosa J. (1978) Factor affecting methl and inorganic mercury dynamics in mussels and shrimp. Mar. Biol. 46, 267-276.

Glickstein N. (1978) Acute toxicity of mercury and selenium to Crassostrea gigas embryos and Cancer magister larvae Mar. Biol. 49, 113-117.

Glickstein N. (1979) The potential loss of dissolved mercury and selenium in marine experimentation. Mar. Pollut Bull. 10, 157.

Green R. A. Jr (1975) Some effects of metals and polychlorinated biphenyls on the estuarine organism, Brachidontes recurvus (Mollusca) and Penaeus setiferus (Crustacea), 83 pp. Masters thesis, Texas A \& M University, U.S.A.

Hsieh M. H. and Chen H. C. (1980) Studies on the toxicity of heavy metals to the intertidal snails. Bull. Malacol. R.O.C. 7, 115-125

Hubert J. J. (1980) Bioassay, 164 pp. Kendall/Hunt, Dubugue, Iowa, U.S.A.

Hung T. C., Han B. C. and Wu S. J. (1989) Green oyster: species and forms of copper in the Charting coastal water. Acta Oceanographica Taiwanica 23, 33-42.

Irukayama K., Kai F., Fusujiki F. and Kondo T. (1962) Studies on the origin of the causative agent of Minamata disease. J. Kumamoto Med. 15, 57-68.

Jones M. B. (1973) Influence of salinity and temperature on the toxicity of mercury to marine and brackish water isopods (crustaceans). Estuarine Coastal mar. Sci. 1, 425-431.

Kitamura S. (1968) Determination of mercury content in bodies of inhabitants, cats, fishes, and shells in Minamata District and in the mud of Minamata Bay. In Minamata Disease pp. 257-266.

Klein D. H., Calabrese A. F., D'Itri M., McKim J. M., Phillips G. R., Reish D. J. and Willford W. A. (1979) Mercury. In A Review of the EPA Red Book: Quality Criteria for Water (Edited by Thurston R. V., Russo R. C., Fetterolf C. M. Jr, Fdsall T. A. and Rarber Y. M. Jr), pp. 145-149. Water Quality Section, American Fisheries Society, Bethesda, Maryland, U.S.A.

Langston W. J. (1982) The distribution of mercury in British estuarine sediments and its availability to deposit-feeding bivalves. J. mar. Biol. Ass. U.K. 62, 667-684.

MacInnes J. R. and Calabrese A. (1978) Response of the embryos of the American oyster, Crassostrea virginica, to heavy metals at different temperatures. In Physiology and Behavior of Marine Organisms (Edited by McLusky D. S. and Berry A. J.), pp. 195-202. Pergamon Press, New York.

Martin M., Osborn K. E., Billig P. and Glickstein N. (1981) Toxicities of ten metals to Crassostrea gigas and Mytilus edulis embryos and Cancer magister larvae. Mar. Pollut. Bull. 12, 305-308.

Martin M. J., Piltz F. M. and Reish D. J. (1975) Studies on Mytilus edulis community in Alamitos Bay, California: V. The effects of heavy metals on byssal thread production. Veliger 18(2), 183-188.

Mohan C. V., Gupta T. R. C., Shetty H. P. C. and Menon N. R. (1986) Combined toxicity of mercury and cadmiun to the tropical green mussel, Perna viridis. Dis. Aquat. Org. 31(2), 65-72.
Moore J. W. and Ramamoorthy S. (1984) Mercury In Heavy Metals in Natural Waters-Applied Monitoring and Impact Assessment (Edited by Desanto R. S.), pp. 77-79. Springer, New York.

Nelson D. A., Calabrese A. and MacInnes J. R. (1977) Mercury stress on juvenile bay scallops, Argopecten irradians, under variours salinity-temperature regimes. Mar. Biol. 43, 293-297.

Nelson D. A., Calabrese A., Nelson B. A., MacInnes J. R. and Wenzloff D. R. (1976) Biological effects of heavy metals on juvenile bay scallops, Argopecten irradians, in short-term exposures. Bull. Environ. Contam. Toxicol. 16, $275-282$.

Okubo K. and Okubo T. (1962) Study on the bioassay method for the evaluation of water pollution-II. Use of the fertilized eggs of sea urchins and bivalves. Bull. Tokai Reg. Fish. Res. Lab. 32, 131-138.

Olson K. R. and Harrell R. C. (1973) Effect of salinity on acute toxicity of mercury, copper, and chromium for Rangia cuneata (Pelecypoda, Mactridae). Contr. Mar. Sci. Univ. Tex. 17, 9-13.

Patin S. A. (1982) Pollution and the Biological Resources of the Oceans (translated by Freund Publishing House, Israel) $135 \mathrm{pp}$. Butterworth Scientific, London.

Roesijadi G., Petrocelli S. R., Anderson J. W., Presley B. J. and Sims R. (1974) Survival and chloride ion regulation of the porcelain crab, Petrolisthes armatus, exposed to mercury. Mar. Biol. 27, 213-217.

Sivaramakrishna B., Radhakrishnaiah $\mathrm{K}$. and Surcsh A (1991) Assessment of mercury toxicity by the changes in oxygen consumption and ion levels in the freshwater snail, Pila globosa, and the mussel, Lamellidens marginalis. Bull. Environ. Contam. Toxicol. 46, 913-920.

Sprague J. B. (1971) Measurement of pollutant toxicity to fish-III: sub-lethal effects and safe concentration. Water Res. 5, 245-266.

Strömgren T. (1982) Effect of heavy metals ( $\mathrm{Zn}, \mathrm{Hg}, \mathrm{Cu}, \mathrm{Cd}$, $\mathrm{Pb}, \mathrm{Ni}$ ) on the length growth of Mytilus edulis. Mar. Biol 72, 69-72.

Trevors J. T. and Lusty C. W. (1985) A basic microcomputer program for calculating $\mathrm{LD}_{50}$ values. Water, Air Soil Pollut. 24, 431-442.

Tseng W. Y. (1976) Study on mass mortallity of cultured shellfishes in the southwestern coast of Taiwan. Bull Taiwan Fish. Res. Inst. 26, 5-35.

Verberg W. B. and Verberg J. (1972) The synergistic effects of temperature, salinity and mercury on survival and metabolism of the adult fiddler crab, Uca pugilator. U.S. Fish. Bull. 70, 415-420.

Wisely B. and Blick R. A. P. (1967) Mortality of marine invertebrate larvae in mercury, copper, and zinc solutions. Aust. J. Mar. Freshwater Res. 18, 63-72.

Woelk C. E. (1965) Biossay with bivalve larvae. Report. Pacific Marine Fisheries Commission 18, 33-35.

Yang H. S. and Ting Y. Y. (1984) Studies on the artificial propagation of the hard clam, Meretrix lusoria Roding Bull. Taiwan Fish. Res. Inst. 36, 99-111.

Yoshida T., Kawabata T. and Matsue Y. (1967) Transference mechanism of mercury in marine environments. Tokyo Univ. Fish. 53, 73-84. 